\title{
Social Media and the Role in Spreading Social Unification Mutes in the Family
}

\author{
Amani Ali ${ }^{1, *}$, Hassad Hassan ${ }^{1}$, and Siti Nurayu Mohd Basir ${ }^{1}$ \\ ${ }^{1}$ School of Human Development and Technocomunication (iKOM), Universiti Malaysia Perlis, 02600 Perlis, Malaysia
}

\begin{abstract}
The effect of new media social not only on the children; but on the whole family was and still has Serious impact and dangerous to the community and the next generation and probably a lot of family relationship failed, and deteriorating. Perhaps explained in this paper some of which can be done to avoid those problems that brought us more of the West and traditions. They try to be with the children as a family with communication. Approximately $60 \%$ of educational concepts and ethics, behavior and belief sourced media. The Toxins That Threaten Our Brain (The reflection of communication in family relation) a. Understanding the wellbeing of the children and young people. b. Issues for consideration in conceptualizing the wellbeing of the children and young people. c. Identify emerging trends concerning the psychological and emotional wellbeing needs of children and young people. Identify and determine the relationships between parents and young people make them able of dealing with others, not only online and away their social and family mutes. At the same time though, overall Internet use keeping family member apart. Online social networks are more than just a fad among the younger generation, "Lynn Franco, director of The Conference Board Consumer Research Center, in a statement. "They've become an integral part of our personal and professional lives. They're an effective way to keep in touch with people, connect with friends and family, and network with colleagues and all that online if they see each other they don't jnow how to communicate."
\end{abstract}

\section{Background of Study}

Family Life may actively follow and track use of social media through its internal logging and audit procedures. All use of Family Life ICT resources may be monitored. But before engaging in social media on behalf of Family Life individuals must be authorized by family to do so. Individuals may not comment as a representative of Family Life unless authorized to do so.

\subsection{Family rules to use of Social Media}

Social media as representative of Family Life individuals must: Always disclose they are worker of Family Life, Ensure that their comments/actions are not harassment. Not respond to material that is offensive, obscene, defamatory, threatening, harassing, bullying, discriminatory, hateful, racist or sexiest. Not use or disclose any confidential or secure information Ensure their comments/actions do not cause an damage to Family Life Devorah Heitner is the author of "Screenwise: Helping Kids Thrive (and Survive) in Their Digital World."2017.

To be effective, family communication must be an exchange of feelings and information. Doors of communication will swing open in the home if members will realize time and participation on the part of all are necessary ingredients. In family discussions, differences should not be ignored, but should be weighed and evaluated calmly Creating a family social media policy In: kids, policy, privacy, rules, social media policy May 26,2011 . One's point or opinion is not as important as a healthy, continuing relationship. Courtesy and respect in listening and responding during discussions are basic in proper dialogue. As we learn to participate together in meaningful associations, we are able to convey out through of love, dependence, and interest. When we are inclined to give up in despair in our efforts to communicate because other family members have failed to respond, perhaps we would do well not to give up, but rather to give and take our conversations. How important it is to know how disagree with another's point of view without being disagreeable. How important it is to have discussion periods ahead of decisions. Jones Stephan wrote, "I have learned that the head does not hear anything until the heart has listened, and that what the heart know today the head will understand tomorrow March 8, 2016 Family technology rules: What kids expect of parents, Jennifer Langston ,UW News."

\subsection{Social media kill communication skills}

With social media consuming so much of our time, conversing with one another face to face has suffered.

* Corresponding author: amaniali@unimap.edu.my 
The busyness of our lives and over scheduling also take a toll on the family. The percentage of families that sit down together to share dinner is steadily declining. Deb McMahon, A Better Iowa contributor Published Sept. 30, 2015.www.desmoinesregister.com/...social-mediakill-communication-skills/73067760/

The dinner table used to be a place where those gathered shared their news of the day. Often it was where families discussed current events and had actuals conversations. Fast food meant was ready at the allotted time, not a bag of greasy takeout to be devoured in record time.

Email, Facebook, Instagram, Twitter, Snap chat and a host of other ways (so many web side) to communicate have often taken the place of talking and sharing. Yes they are fast, available at all hours and easy, who take the place of verbal discussions. A Work-InProcess Literature Review: Incorporating Social Media in Risk and Crisis Communication .Shari R. Veil,Tara Buehner,Michael J. Palenchar First published: 4 April 2011Full publication history DOI: 10.1111/j.14685973.2011.00639.x View/save citation Cited by (CrossRef): 109 articles

Throughout the last decade as social media has progressed into the homes of nearly 2 billion people around the world many lasting relationships have been formed, friendships have bonded and, wait for it, personal social interaction has seemingly declined. What is the point in meeting a friend face to face when we chat with them all night long if we choose to and we never have to leave the comfort of our own home?

\section{Family Communication Plan for Parents and Kids}

\subsection{Simply solve family problem}

For many families, eating together is a lost art. According to recent surveys, less than families sit down to a meal together on a regular basis. Typically, everyone grabs something to eat on their way to band or football practice, a soccer game, a play rehearsal or when coming home late from work or the gym. What's dinnertime like in your home? The importance of the event cannot be underestimated. The evening meal is a key time for families to reconnect, share the day's event, and continue deepening their knowledge of each other. Simply put, making time to eat dinner. How Social Media Kills Face-to-Face Conversation by Meg Lenzkes ..https://prezi.com/v6yz-wvpizfc/how-social-media-killsface-to-face-conversation/Jun 6, 2017.

\subsection{Example for that things that are being killed by the internet conversation}

Today our thumbs get more exercise than our vocal chords. Like a premise for a dystopian novel, our generation has almost forgotten how to speak because we're too busy typing. We're guilty of texting instead of talking over coffee and Facebook chatting instead of conversing on the phone. It's as if we've sacrificed the art of conversation for the art of convenience. We opt for three-hour text conversations over face- to-face ones. Texting and Facebook chatting allow us to step away and take time to think and respond, while talking in person allows us to cultivate our skill of asking, listening, and responding in the moment.

\section{Result and Solution}

-If you are too busy for a family meal, you may too busy. Keep things simple. Plan ahead for a quick meal and be flexible if adjustments are needed at the last minute. It's worth it to get everyone together.

-Turn off the TV. A blaring television is distracting and discourages conversation. If you normally watch TV during dinner, decrease the habit slowly by having one or two TV-free meals everyday week. When your kids see you follow through, they'll begin to understand the dinner time is important.

-Don't slave the other stove. Elaborate meals are not a key ingredient for family fellowship.

-Involve the kids. Have your children help plan, prepare, and serve meals. This builds teamwork and cooperation. Give children "joy" jobs as setting the table, reading recipes, mixing and stirring food, and clearing the table.

-Show, don't tell. When you make nurturing family mealtimes a priority, your kids will notice and, someday, understand benefits.

\subsection{Encouraging children to communicate}

Good communication is important. It can help you and your children do well in work and school. Families who communicate get along better. There are many ways to communicate. One way to better communicate with your children is to spend more time with them. Isa group that helps families do things together. $4-\mathrm{H}$ teaches us how to communicate better. Any children ages 5-9 can be a member of adults can volunteer their time to work with 4-H as leaders has lots of projects that families can do together. 4-H helps youth members learn to speaking public. Members can also learn communicate through writing. In members and adults leaders learns to work well with others. Members and leaders become part of a team. Being part of the team means members communicate with other children and adults in their area.

\subsection{Learning to listen each other}

Listening to your family shows that you care and that you think the other person is important. Listening takes some time and means you really have to understand what the other person is saying. Maybe you never be taught how to listen to someone else. Learning how to listen is easy. You must look at the person, concentrate or think about what is said, and repeat it. This shows that you heard what the person meant to say. This shows you care 
enough to listen to what your partner is saying. A good way to remember how to listen is: Look, Think, and Repeat. For example, when your partner says, "Work was really hard today," what is he/she saying? How can you show you are listening? Look, think, and repeat. First, look into your partner's eyes to show you are listening. Next, think about what your partner saying. Work was really hard today might means a lot of different things. It might mean someone at work was making it hard to get work done or someone angry or that your partner was too tired to get work done. Pick one, pick what you think it means and repeat it. Say, "Work was hard today because you were tired." Even if you are not right about your partner said, you tried. Your partner will either agree with what you heard or tell you something like, "I was angry because the supervisor made us re-do what we did last week."

\section{Conclusion}

Web technology itself hasn't undermined the foundations of the institution of the family. We've been doing that to families without it for centuries. What seems to be happening is that out online activity is actually reversing a worrying trend. So go on, post that video of Grandma on the Xbox to YouTube. She may not thank you for it now, because we trapped in new media more than any time ever. www.telegraph.co.uk, Technology,Sep 4, 2009 - The internet has wrought huge changes on our lives

Another way that the world of social media is killing you through the decreasing levels of self-esteem and overall confidence that can quickly occur because of the cyber-bullying and overall negativity that is directed toward people online. For example, you might decide to post a picture of yourself during a past beach vacation and automatically become bombarded by comments from your friends, coworkers and relatives about how unflattering you look in that particular picture Learning to listen to one another NIcholas Becker, https://a9a1263f9caafb223a0e-

rackcdn.com/images/pgmisc/pg-logo-800px-

transparentbg.png.

Even if they are joking, these types of negative comments cause people to become more self-conscious about their appearance to the point where they are skeptical about posting any other pictures of themselves. In more extreme cases, this major deficiency in selfimage and overall confidence can force a person to live an introverted lifestyle, feeling that they would probably just be better off not exposing themselves to other people at all instead off just through online pictures. Studies have proven that a key reason why many people would rather post pictures of other people, viral images and other subject instead of pictures of themselves is primarily because they are ashamed of the way that they look and are afraid about how other people may react if they were to see those pictures https://familylife.com.au/about-familylife/governance...role-of.../social-media-policy/ Family
Life's social media policy is based on the Department of Justice Social Media.

I wonder what would have happened if religious teaching would have just mass texted all his teachings, Facebook posted all his parables, and started a blog with pictures of all his miracles, before and after. "Follow me by putting in your email address!" I'm thinking it wouldn't have had the same impact as his face-to-face ministry.

\section{References}

1. "Author Nicholas Carr: The Web Shutters Focus, Rewires Brains | Magazine." Wired.com. 4 July 2010

2. "Boston Globe: Instant gratification is making us perpetually impatient, Feb 2013."

3. "Carr, Pinker, the shallows, and the nature-nurture canard: neutron culture". Scienceblogs.com. 20 September 2011.

4. "Children and Parents: Media Use and Attitudes Report”(PDF). Ofcom. 23 October 2012. February 2013.

5. "CNN: Online viewers ditch slow-loading video after 2seconds, November 2012".

6. "Digital power: exploring the effects of social media on children's spirituality".

7. "NPR Morning Edition: In Video-Streaming Rat Race, Fast is Never Fast Enough, October 2012".

8. "Patience is a Network Effect, by Nicholas Carr, November 2012"

9. "Science Daily: How Online Video Streaming Quality Affect Viewer Behavior, November 2012".

10. "The effects of the Internet: Fast forward." The Economist. July 2010

11. "Video Stream Quality Impact Viewer Behavior, by Krishnan and Sitaraman, ACM Internet Conference" (PDF). November 2012.

12.2011, Neuron Culture : the shallows and naturenurture. Sciencebloges.com

13. Cyber bullying: Bullying in the Digital Age.

14. Goldsmith, Belinda (31 march 2007). "Web news readers have greater attention span: study." Reuters. February 2013

15. Helen Briggs (11 January 2012). "Web addict have brain changes, research suggests". BBC News. 17 March 2013

16. Jessie Connell, "Parent' Use of Technology and the Internet" (University of Minnesota, 2012)

17. Q. Li, Journal of aggression, Maltreatment and trauma, 372 - 392 (2010)

18. Mary Madden, Sandra Cortesi, Urs Gasser, Amanda Lenhart, Maeve Duggan (20 November 2012. "Parents, Teens, and Online Privacy". Pew Research Center. 10 February 2013

19. G. Mesch, The Journal of Family Communication: $119-138$ (2007)

20. Pinker, Steven (2010-06-10). "Mind over Mass Media." The New York Times. 4July 2010. 
21. Rowan Pelling (22 May 2012).'How technology is taking hold of our children's lives". Telegraph. 26 May 2012

22. G. Sanford, M. H. Stephanie, P. Susie, Y. Amber, Advances in Consumer Research 29, 66- 70 (2002)

23. Schmidt, Alex (12 October 2011). "Immigrant Parent Rely On Kids For Help Online.” NPR. 10 February 2013.

24. M. Sussman, S. Suzanne, Handbook of Marriage and the Family (New York: Plenum Press, 1987)

25. The Patience Deficit, by Nicholas Carr, December 2013.

26. K. Yuan, W. Qin, G. Wang, F. Zeng, L. Zhao, "Microstructure Abnormalities in Adolescents with Internet Addiction Disorder". 6(6), 20708 (2013) .doi:10.1371/journal.pone.0020708. PMC 3108989. PMID 21677775.17 March 2013 